\title{
In search of the Latest Danian Event in a paleobathymetric transect off Kasserine Island, north-central Tunisia
}

\author{
J. Sprong a , T.J. Kouwenhoven a, ${ }^{\text {, }}$, A. Bornemann ${ }^{\text {b }}$, C. Dupuis ${ }^{\text {c }}$, R.P. Speijer ${ }^{\text {a, }}{ }^{2}$, P. Stassen ${ }^{\text {a }}$, E. Steurbaut ${ }^{\text {a,d }}$ \\ a Department of Earth, and Environmental Sciences, KU Leuven, Celestijnenlaan 200E, B-3001 Leuven, Belgium \\ b Institute of Geophysics and Geology, Universität Leipzig, Talstraße 35, 04103 Leipzig, Germany \\ c GFA, Faculté Polytechnique de Mons, Rue de Houdains 9, 7000 Mons, Belgium \\ d Royal Belgian Institute of Natural Sciences, Vautierstraat 29, B-1000 Brussels, Belgium
}

\section{A R T I C L E I N F O}

\section{Article history:}

Received 21 May 2012

Received in revised form 22 January 2013

Accepted 24 January 2013

Available online 1 February 2013

\section{Keywords:}

Paleocene

Tunisia

Benthic foraminifera

Stable isotopes

Latest Danian Event

\begin{abstract}
A B S T R A C T
Danian (lower Paleocene) sequences in north-central Tunisia are dominantly composed of marls and shales but a conspicuous, indurated glauconite-bearing marker bed is associated with the P3a-P3b transition. This glauconite bed is considered to correlate with the Latest Danian Event (LDE) described from the Nile Basin in Egypt, with the 'top Chron C27n event' (Atlantic and Pacific Oceans) and with the 'CIE-DS1' (Zumaia, Spain). The LDE is thought to reflect a short period of global warming, similar to the Paleocene Eocene Thermal Maximum, but of lesser magnitude. The presence of a glauconitic bed at the P3a/P3b transition in Tunisia suggests that the sequence is condensed, which is confirmed by planktic foraminifer and nannofossil biostratigraphy, and by the absence of the typical LDE beds found in most Egyptian sections. Benthic foraminiferal assemblages were quantitatively analyzed in three sections in north-central Tunisia (Sidi Nasseur, Garn Halfaya, Elles) in order to characterize the paleoenvironmental evolution during the late Danian and compare this with sections in Egypt. The benthic foraminiferal assemblages indicate that the Tunisian sections were located along a depth- and a paleoenvironmental gradient on the shelf north of Kasserine Island. The reconstructed depth range is comparable with sections in Egypt, and encompasses middle neritic (Sidi Nasseur section) to shallow upper bathyal depths (Elles section, with up to 16\% Gavelinella beccariiformis below the P3a/P3b). Like in Egypt, assemblage shifts across the P3a/P3b subzonal transition indicate shallowing and a transition to a more eutrophic paleoenvironment, characterized by relatively high abundances of buliminids and Stainforthia sp. The $\delta^{13} \mathrm{C}$ and $\delta{ }^{18} \mathrm{O}$ records generated on well-preserved specimens of the ostracode species Bairdia failed to demonstrate the presence of the carbon isotope excursion (CIE) associated with the LDE at the base of Subzone P3b. A condensed section or a hiatus associated with the glauconite bed would explain why the CIE is not recorded in the Tunisian sections.
\end{abstract}

(C) 2013 Published by Elsevier B.V.

\section{Introduction}

The Latest Danian Event (LDE, 61.7 Ma), first recorded in sections in the Nile Basin, Egypt (Fig. 1A) has been suggested to represent a mild precursor of the Paleocene Eocene Thermal Maximum (PETM: Speijer, 2000, 2003; Bornemann et al., 2009; Schulte et al., 2013). It is time-equivalent with the 'CIE-DS1' carbon isotope excursion at Zumaia (Spain: Arenillas et al., 2008; Dinarès-Turell et al., 2010; Schmitz et al., 2011; Monechi et al., 2013), and with the 'top Chron C27n event', defined from a carbonate dissolution horizon observed at ocean drilling (ODP) sites in the Atlantic and Pacific Oceans (Westerhold et al., 2008, 2011). A $\sim 2{ }^{\circ} \mathrm{C}$ sea floor warming inferred from $\delta^{18} \mathrm{O}$ data of ODP Site 1209 (Shatsky Rise, Pacific Ocean)

\footnotetext{
* Corresponding author. Tel.: + 3216 326404; fax: + 3216322980 .

E-mail addresses: t.j.kouwenhoven@uu.nl (T.J. Kouwenhoven), Robert.Speijer@ees.kuleuven.be (R.P. Speijer).

${ }^{1}$ Presently at: Department of Geology, Utrecht University, Budapestlaan 4, 3584 CD Utrecht, The Netherlands.
}

indicates that the LDE indeed represents a global hyperthermal event (Westerhold et al., 2011).

Steurbaut and Sztrákos (2008), studying a Danian-Selandian succession in southern France proposed that the LDE is associated with a change in sedimentation regime, identified from the southern Tethys up to the North Sea Basin and resulting from a major sea-level fall. The LDE was previously correlated with the Danian-Selandian boundary (e.g., Speijer, 2003); however, formal definition of the GSSP of the D-S boundary in the Zumaia section (Schmitz et al., 2011) now places the LDE in the latest Danian (Bornemann et al., 2009; Sprong et al., 2012). It is one in a row of Paleocene candidate hyperthermals together with the early Paleocene Dan-C2 event ( 65.2 Ma: Quillévéré et al., 2008; Coccioni et al., 2010), and the Early Late Paleocene Event (ELPE: Petrizzo, 2005) or Mid-Paleocene Biotic Event ( 58.7 Ma: MPBE, Bernaola et al., 2007; Westerhold et al., 2011) (Fig. 2).

At approximately the same biostratigraphic level as the LDE, a conspicuous glauconite-bearing marker bed can be traced throughout north-central Tunisia (Fig. 1B; e.g., Steurbaut et al., 2000; Guasti et al., 2006; Van Itterbeeck et al., 2007; Sprong et al., 2009). Although the 